\title{
Clinical Significance of R202Q Alteration of MEFV Gene in Children With Familial Mediterranean Fever
}

\author{
Tufan ÇANKAYA, ${ }^{1}$ Elçin BORA, ${ }^{1}$ Meral TORUN BAYRAM, ${ }^{2}$ Ayfer ÜLGENALP, ${ }^{1}$ \\ Salih KAVUKÇU, ${ }^{2}$ Mehmet Atilla TÜRKMEN, ${ }^{2}$ Alper SOYLU ${ }^{2}$ \\ ${ }^{1}$ Department of Pediatric Genetics, Medical Faculty of Dokuz Eylül University, İzmir, Turkey \\ ${ }^{2}$ Department of Pediatric Nephrology, Medical Faculty of Dokuz Eylül University, İmir, Turkey
}

\begin{abstract}
Objectives: This study aims to investigate the clinical impact of the R202Q (c.605G >A) alteration of Mediterranean fever (MEFV) gene in children with familial Mediterranean fever (FMF).

Patients and methods: Medical records of 115 patients (51 males, 64 females; mean age $6.6 \pm 3.8$ years; range 8 months to 15.8 years) presenting with FMF pre-diagnosis were examined. Patients were classified into two groups based on number of mutated alleles (one-mutant allele and twomutant alleles), and these groups were classified into three subgroups (Group 1; subgroup 1: M694V/R202Q, subgroup 2: M694V/other, subgroup 3: other/other, and Group 2; subgroup 4: R202Q/-, subgroup 5: other/-, subgroup 6: -/-). Sex, age, abdominal pain, fever, arthritis or arthralgia, myalgia, erysipelas-like erythema, chest pain, amyloidosis, family history of FMF, and definitive FMF frequency were compared between groups.

Results: The most common allele alterations were the heterozygous R202Q alteration (27\%) and the compound heterozygous mutation M694V/ R202Q (20.9\%). The R202Q alteration of MEFV gene was detected in 76 patients (66\%) (15 homozygous). There was non-M694V (E148Q, V726A) mutation in two of these patients. One (50\%) of the patients with isolated R202Q homozygous alteration and six (19\%) of the patients with isolated R202Q heterozygous alteration had definitive FMF. In the two-mutant allele group; abdominal pain, fever, arthritis/arthralgia, and definitive FMF frequency were lower in subgroup 1 than subgroup 2. There was no significant difference in clinical findings and definitive FMF frequency between subgroup 2 and subgroup 3 . In the one-mutant allele group, clinical findings did not differ between subgroups.

Conclusion: R202Q alteration of the MEFV gene may lead to symptoms consistent with FMF. However, R202Q/M694V compound heterozygosity is more associated with mild phenotype than compound heterozygous mutation of M694V.

Keywords: Children; familial Mediterranean fever; R202Q alteration of MEFV gene.
\end{abstract}

Familial Mediterranean fever (FMF; OMIM 249100) is a genetic disease inherited as an autosomal recessive trait. It is characterized by recurrent fever, abdominal pain, chest pain, arthritis/arthralgia, myalgia, erythema and, rarely, severe myalgias, such as protracted febrile myalgia, pericarditis and acute orchitis attacks. ${ }^{1}$ Although attacks are self-limited, some patients developed amyloidosis that leads to renal failure. ${ }^{2}$ FMF primarily affects populations surrounding the Mediterranean basin, mainly Sephardic and Ashkenazi Jews, Armenians, Turks and Arabs. ${ }^{3,4}$
In 1997, the gene for FMF (MEFV) was mapped to chromosome $16 .{ }^{5}$ The gene comprises 10 exons and encodes a 781-amino acid protein called marenostrin or pyrin. ${ }^{6}$ Pyrin is only expressed in neutrophils and monocytes, and has an important role in the caspase- 1 and interleukin-1 $\beta$ pathways. These pathways lead to apoptosis-associated protein expression and antiinflammatory activity. ${ }^{7}$

Up to the present time, over 283 gene alterations (mutations or polymorphisms) in the MEFV gene have been described, of which 12 are

Received: December 19, 2013 Accepted: April 20, 2014 Published online: February 05, 2015

Correspondence: Meral Torun Bayram, M.D. Dokuz Eylül Üniversitesi Tıp Fakültesi, Çocuk Genetik Hastalıkları Bilim Dalı, 35210 Alsancak, İzmir, Turkey.

Tel: +90 505 - 2136331 e-mail: meralt.bayram@yahoo.com.tr

Presented at the $14^{\text {th }}$ Congress of Rheumatology, September 11-15, 2013, Izmir, Turkey

○2015 Turkish League Against Rheumatism. All rights reserved. 
the most frequent. ${ }^{8}$ In the majority (80\%) of FMF cases, the mutations reside within the last exon. Other less common allele mutations have been shown in exons 2, 3 and 5.,5 These mutations are E148Q in exon 2, P369S in exon 3, F479L in exon 5, M680I, I692del, M694V, K695R, M694I, V726A, A744S, and R761H in exon $10 .^{1}$

The association between the disease and many MEFV gene alterations has been clearly established. However, controversy exists regarding the role of some amino acid substitutions, particularly for R202Q in exon 2, where a $\mathrm{G}>\mathrm{A}$ transition at nucleotide 605 results in glutamine (Q) substituting for arginine (R). R202Q was reported as a frequent polymorphism, and the $\mathrm{G}$ allele of the mutation was in linkage disequilibrium with M694V. ${ }^{8}$ Nevertheless, previous studies demonstrated that the $\mathrm{R} 202 \mathrm{Q}$ polymorphism might be a diseasecausing mutation. ${ }^{10-12}$ However, the clinical significance of the $\mathrm{R} 202 \mathrm{Q}$ alteration of MEFV gene has not been evaluated in children thus far. In this study, we aimed to investigate the clinical impact of the R202Q alteration of MEFV gene in children with FMF.

\section{PATIENTS AND METHODS}

We retrospectively evaluated the medical records of 115 patients (51 males, 64 females; mean age $6.6 \pm 3.8$ years; range 8 months to 15.8 years) who presented with a FMF pre-diagnosis in Pediatric Nephrology Department of Dokuz Eylul University Medical School between October 2010 and August 2013. The diagnosis of FMF was established according to the Tel-Hashomer criteria. ${ }^{13}$ Major criteria are: (i) recurrent febrile episodes accompanied by peritonitis, pleuritis, and synovitis, (ii) amyloidosis of the AA type without predisposing disease, and (iii) response to colchicine treatment. Minor criteria are: (i) recurrent febrile episodes, (ii) erysipelas-like erythema, and (iii) FMF in a first-degree relative. Patients were divided into three groups according to the Tel-Hashomer criteria. These groups were defined as definitive FMF (patients with two major or one major plus two minor criteria), probable FMF (patients with one major plus one minor criteria), and suspicious FMF (patients with one major or one minor criteria).
Patients were also classified into two main groups regarding mutated alleles, either of which had three subgroups. The two-mutant allele group included subgroup 1 (M694V/R202Q), subgroup 2 (M694V/other) and subgroup 3 (other/other). The one-mutant allele (heterozygote) and non-mutant group included subgroup 4 (R202Q/-), subgroup 5 (other/-) and subgroup 6 (-/-). Statistical methods were used to compare demographic and clinical findings between subgroups within each group. These findings include sex, age at diagnosis and onset of symptoms (month), abdominal pain, fever, arthritis or arthralgia, myalgia, erysipelaslike erythema, chest pain, amyloidosis, family history of FMF, and definitive FMF.

Genomic DNA was isolated from peripheral leukocytes, using the QIAamp DNA Blood Mini Kit (Qiagen Inc., Valencia, CA, USA) according to the manufacturer's instructions. A reverse hybridization, test strip-based assay (FMF Strip Assay; Vienna Lab Labodiagnostika, Vienna, Austria) was used according to the manufacturer's instructions to test patients for the presence of mutations. The first step consisted of a multiplex polymerase chain reaction analysis using biotinylated primers to amplify the exons. The polymerase chain reaction products were then selectively hybridized to a test strip containing a parallel array of allele-specific oligonucleotide probes. Hybridizations were illuminated by the reaction of streptavidin-alkaline phosphatase and a color substrate. ${ }^{14}$

\section{Statistical analysis}

Results were given as mean \pm standard deviation for age and as percentage for genotype frequencies. Subgroups within each group were compared in terms of demographic and clinical findings with the Student's t, Mann-Whitney U, and Chi-square tests. Classified variables in subgroups with fewer than five patients were compared with Fisher's exact test. A $p$ value of $<0.05$ was considered statistically significant. SPSS software version 16.0 (SPSS Inc., Chicago, IL, USA) was used for statistical analysis.

\section{RESULTS}

The mean ages at diagnosis and onset of symptoms were $6.8 \pm 4.4$ and $5.5 \pm 4.4$ years for males 


\begin{tabular}{|c|c|c|}
\hline Genotype & $\mathrm{n}$ & $\%$ \\
\hline Mutation (-) & 18 & 17.7 \\
\hline \multicolumn{3}{|c|}{ Heterozygous for one mutation } \\
\hline $\mathrm{R} 202 \mathrm{Q} /-$ & 31 & 27 \\
\hline E148Q/- & 5 & 4.3 \\
\hline V726A/- & 2 & 1.7 \\
\hline M680I/- & 2 & 1.7 \\
\hline A744I/- & 1 & 0.9 \\
\hline $\mathrm{R} 761 \mathrm{H} /-$ & 1 & 0.9 \\
\hline K695R/- & 1 & 0.9 \\
\hline \multicolumn{3}{|l|}{ Homozygous for one mutation } \\
\hline $\mathrm{R} 202 \mathrm{Q} / \mathrm{R} 202 \mathrm{Q}$ & 2 & 1.7 \\
\hline $\mathrm{E} 148 \mathrm{Q} / \mathrm{E} 148 \mathrm{Q}$ & 1 & 0.9 \\
\hline M694V/M694V & 1 & 0.9 \\
\hline \multicolumn{3}{|c|}{ Homozygous for two mutations } \\
\hline R202Q/M694V & 8 & 7.0 \\
\hline \multicolumn{3}{|c|}{ Compound heterozygous for two mutations } \\
\hline R202Q/M694V & 24 & 20.9 \\
\hline M694V/E148Q & 2 & 1.7 \\
\hline M694V/M680I & 2 & 1.7 \\
\hline R202Q/E148Q & 1 & 0.9 \\
\hline E148Q/P369S & 1 & 0.9 \\
\hline M694V/V726A & 1 & 0.9 \\
\hline $\mathrm{R} 202 \mathrm{Q} / \mathrm{V} 726 \mathrm{~A}$ & 1 & 0.9 \\
\hline \multicolumn{3}{|c|}{ Compound heterozygous for three mutations } \\
\hline R202Q/R202Q/M694V & 5 & 4.3 \\
\hline R202Q/M694V/V726A & 2 & 1.7 \\
\hline $\mathrm{R} 202 \mathrm{Q} / \mathrm{M} 694 \mathrm{~V} / \mathrm{R} 761 \mathrm{H}$ & 1 & 0.9 \\
\hline R202Q/M680I/M694V & 1 & 0.9 \\
\hline E148Q/E148Q/P369S & 1 & 0.9 \\
\hline Total & 115 & 100 \\
\hline
\end{tabular}

and females, respectively. Of the 115 patients, 38 (33\%) had definitive FMF (two of these had previously protracted febrile myalgia), 37 (32\%) had probable FMF, and 35 (30.4\%) had suspicious FMF according to the Tel-Hashomer criteria. Also, four patients (3.5\%) had a history of prolonged abdominal pain due to Henoch-Schönlein purpura, and one (0.9\%) patient had a history of ureter thickness.

The genotypes of patients are summarized in Table 1. The most common alteration of MEFV genes was isolated R202Q, which was detected in 31 patients (27\%) in heterozygous form. Another common alteration of MEFV genes was the compound heterozygote mutation M694V/ $\mathrm{R} 202 \mathrm{Q}$, which was detected in 24 patients (20.9\%). However, the R202Q alteration of MEFV genes was detected in 76 patients (66\%) (15 of which were homozygous). There were nonM694V (E148Q, V726A) mutations in two of these patients (Table 2).

The clinical features of two-allele and one-allele mutated patients are shown in Tables 3 and 4, respectively. Table 3 shows two-allele mutated subgroups: subgroup 1 (M696V/R202Q) had 24 patients, subgroup 2 (M694V/other) had five patients, and subgroup 3 (other/other) had six patients. Table 4 shows one-allele mutated groups: subgroup 4 (R202Q heterozygote) had 31 patients, subgroup 5 (non-R202Q heterozygote) had 12 patients, and subgroup 6 (non-mutation) had 18 patients.

Abdominal pain, fever, arthritis/arthralgia, and definitive FMF frequencies were higher in subgroup 2 than subgroup 1 . However, the frequencies were not different between subgroups 1 and 3 (Table 3). In addition, the clinical features and definitive FMF frequency did not differ between one-mutant allele subgroups.

Two patients had the R202Q homozygous alteration; of these patients, one had definitive

Table 2. Genotypic distribution of R202Q (c.605G >A p.Arg202Gln) polymorphism

\begin{tabular}{|c|c|c|c|c|c|c|}
\hline & \multicolumn{6}{|c|}{ R202Q (c.605G>A p.Arg202Gln) } \\
\hline & \multicolumn{2}{|c|}{$\begin{array}{c}\text { GG } \\
\text { (Normal) }\end{array}$} & \multicolumn{2}{|c|}{$\begin{array}{c}\text { GA } \\
\text { (Heterozygous) }\end{array}$} & \multicolumn{2}{|c|}{$\begin{array}{c}\mathrm{AA} \\
\text { (Homozygous) }\end{array}$} \\
\hline & $\mathrm{n}$ & $\%$ & $\mathrm{n}$ & $\%$ & $\mathrm{n}$ & $\%$ \\
\hline All patients & 39 & 34 & 61 & 53 & 15 & 13 \\
\hline M694V/M694V & 1 & 11 & - & - & 8 & 89 \\
\hline M694V/- & 5 & 15 & 24 & 70 & 5 & 15 \\
\hline E148Q/- & 5 & 83 & 1 & 17 & - & - \\
\hline V726A/- & 2 & 66 & 1 & 34 & - & - \\
\hline M694V/V726A & 1 & 34 & 2 & 66 & - & - \\
\hline M694V/R761H & - & - & 1 & 100 & - & - \\
\hline M694V/M680I & 2 & 66 & 1 & 34 & - & - \\
\hline No mutation & 18 & 35 & 31 & 61 & 2 & 4 \\
\hline
\end{tabular}


Table 3. Relationship between genotype and clinical findings in patients with two-allele change

\begin{tabular}{|c|c|c|c|c|c|c|c|c|c|c|c|c|}
\hline & \multicolumn{3}{|c|}{$\begin{array}{l}\text { M694V/R202Q } \\
\text { Group } 1(n=24)\end{array}$} & \multicolumn{3}{|c|}{$\begin{array}{l}\text { M694V/other } \\
\text { Group } 2(n=5)\end{array}$} & \multicolumn{3}{|c|}{$\begin{array}{l}\text { Other/other } \\
\text { Group } 3(n=6)\end{array}$} & \multirow[b]{2}{*}{$p^{*}$} & \multirow[b]{2}{*}{$p^{* *}$} & \multirow[b]{2}{*}{$p^{* * * *}$} \\
\hline & $\mathrm{n}$ & $\%$ & Mean \pm SD & $\mathrm{n}$ & $\%$ & Mean \pm SD & $\mathrm{n}$ & $\%$ & Mean \pm SD & & & \\
\hline Sex & & & & & & & & & & 0.266 & 0.308 & 0.608 \\
\hline Males & 16 & & & 2 & & & 3 & & & & & \\
\hline Females & 8 & & & 3 & & & 3 & & & & & \\
\hline Age at diagnosis (years) & & & $4.3 \pm 2.4$ & & & $10.1 \pm 6.8$ & & & $8.9 \pm 3.6$ & 0.049 & 0.066 & 0.881 \\
\hline Age at onset of symptoms (years) & & & $3.1 \pm 2.0$ & & & $4.3 \pm 1.8$ & & & $3.1 \pm 5.8$ & 0.412 & 0.556 & 0.343 \\
\hline Abdominal pain & 6 & 26 & & 5 & 100 & & 4 & 67 & & 0.011 & 0.086 & 0.273 \\
\hline Fever & 7 & 29 & & 5 & 100 & & 3 & 50 & & 0.005 & 0.306 & 0.121 \\
\hline Arthritis/arthralgia & 4 & 18 & & 3 & 60 & & 2 & 40 & & 0.007 & 0.303 & 0.500 \\
\hline Myalgia & 2 & 9 & & - & - & & - & - & & 0.091 & 0.658 & - \\
\hline Erythema & 1 & 5 & & - & - & & - & - & & 0.658 & 0.793 & - \\
\hline Chest pain & - & - & & 2 & 40 & & 1 & 20 & & 0.821 & 0.185 & 0.500 \\
\hline Amyloidosis & - & - & & - & - & & - & - & & - & - & - \\
\hline Family history & 20 & 83 & & 4 & 80 & & 2 & 50 & & 0.642 & 0.029 & 0.175 \\
\hline Definitive/probable FMF & $8 / 0$ & & & $5 / 0$ & & & $2 / 2$ & & & & 0.091 & 0.167 \\
\hline Definitive/suspicious FMF & $8 / 16$ & & & $5 / 0$ & & & $2 / 1$ & & & 0.011 & 0.303 & 0.375 \\
\hline Definitive FMF & 8 & 33 & & 5 & 100 & & 2 & 33 & & 0.011 & 0.576 & 0.083 \\
\hline
\end{tabular}

FMF and the other had suspicious FMF. Thirty-one patients had the R202Q heterozygous alteration and six (\%19) of these had definitive FMF.

\section{DISCUSSION}

The most frequent MEFV gene mutations in Turkish FMF patients were M694V, M680I, V726A, and E148Q, which ranged from $28.6-51.4 \%, 7.6-15.8 \%, 4.9-9.7 \%$ and $3.5-16.3 \%$ of patients, respectively. ${ }^{15}$ The frequency of heterozygous and homozygous R202Q alleles in FMF patients ranged from $31.6-59.6 \%$ and 9.2-14.7\%, respectively. ${ }^{10,16,17}$ In these studies and one previous study, the frequency of the heterozygous R202Q allele was demonstrated to be similar in both FMF patients and a control group. However, the frequency of the homozygous R202Q allele was significantly higher in FMF patients than in healthy controls. ${ }^{10,16,17}$ In our study, there was no control group. However, the frequency of heterozygous and homozygous

Table 4. Relationship between genotype and clinical findings in patients with one-allele

\begin{tabular}{|c|c|c|c|c|c|c|c|c|c|c|c|c|}
\hline & \multicolumn{3}{|c|}{$\begin{array}{c}\text { R202Q/- } \\
\text { Group } 4(n=31)\end{array}$} & \multicolumn{3}{|c|}{$\begin{array}{l}\text { Non-R202Q/- } \\
\text { Group } 5(\mathrm{n}=12)\end{array}$} & \multicolumn{3}{|c|}{$\begin{array}{c}-/- \\
\text { Group } 6(n=18)\end{array}$} & \multirow[b]{2}{*}{$p^{*}$} & \multirow[b]{2}{*}{$p^{* *}$} & \multirow[b]{2}{*}{$p^{* * * *}$} \\
\hline & $\mathrm{n}$ & $\%$ & Mean $\pm \mathrm{SD}$ & $\mathrm{n}$ & $\%$ & Mean \pm SD & $\mathrm{n}$ & $\%$ & Mean \pm SD & & & \\
\hline Sex & & & & & & & & & & 0.631 & 0.388 & 0.466 \\
\hline Males & 13 & & & 5 & & & 6 & & & & & \\
\hline Females & 18 & & & 7 & & & 12 & & & & & \\
\hline Age at diagnosis (years) & & & $7.9 \pm 4.2$ & & & $5.3 \pm 3.8$ & & & $6.3 \pm 5.3$ & 0.255 & 0.680 & 0.527 \\
\hline Age at onset of symptoms (years) & & & $6.6 \pm 3.9$ & & & $5.3 \pm 3.8$ & & & $6.3 \pm 5.3$ & 0.454 & 0.876 & 0.668 \\
\hline Abdominal pain & 17 & 55 & & 7 & 58 & & 9 & 56 & & 0.556 & 0.587 & 0.609 \\
\hline Fever & 16 & 52 & & 7 & 58 & & 7 & 41 & & 0.479 & 0.349 & 0.297 \\
\hline Arthritis/arthralgia & 10 & 32 & & 3 & 25 & & 6 & 35 & & 0.471 & 0.538 & 0.432 \\
\hline Myalgia & 5 & 16 & & 1 & 8 & & 1 & 6 & & 0.455 & 0.322 & 0.683 \\
\hline Erythema & 2 & 6 & & - & - & & 1 & 6 & & 0.515 & 0.717 & 0.586 \\
\hline Chest pain & 3 & 10 & & - & - & & - & - & & 0.364 & 0.277 & - \\
\hline Amyloidosis & - & - & & - & - & & - & - & & - & - & - \\
\hline Family history & 10 & 33 & & 5 & 45 & & 6 & 38 & & 0.359 & 0.513 & 0.492 \\
\hline Definitive/probable FMF & $6 / 16$ & & & $1 / 6$ & & & $5 / 9$ & & & 0.444 & 0.431 & 0.314 \\
\hline Definitive/suspicious FMF & $6 / 8$ & & & $1 / 4$ & & & $5 / 4$ & & & 0.366 & 0.433 & 0.238 \\
\hline Definitive FMF & 6 & 19 & & 1 & 8 & & 5 & 28 & & 0.356 & 0.367 & 0.204 \\
\hline
\end{tabular}


Table 5. Clinical comparison of M694V/R202Q and M694V/R202Q/R202Q gene change

\begin{tabular}{|c|c|c|c|c|c|c|c|}
\hline & \multicolumn{3}{|c|}{$\begin{array}{c}\text { M694V/R202Q } \\
(\mathrm{n}=24)\end{array}$} & \multicolumn{3}{|c|}{$\begin{array}{c}\text { M694V/R202Q/R202Q } \\
(\mathrm{n}=5)\end{array}$} & \multirow[b]{2}{*}{$p^{*}$} \\
\hline & $\mathrm{n}$ & $\%$ & Mean \pm SD & $\mathrm{n}$ & $\%$ & Mean \pm SD & \\
\hline Sex & & & & & & & 0.078 \\
\hline Males & 16 & & & - & & & \\
\hline Females & 8 & & & 4 & & & \\
\hline Age at diagnosis (years) & & & $4.3 \pm 2.4$ & & & $6.8 \pm 4.4$ & 0.933 \\
\hline Age at onset of symptoms (years) & & & $3.1 \pm 2.0$ & & & $5.5 \pm 4.4$ & 0.571 \\
\hline Abdominal pain & 6 & 26 & & 2 & 50 & & 0.172 \\
\hline Fever & 7 & 29 & & 2 & 50 & & 0.209 \\
\hline Arthritis/arthralgia & 4 & 18 & & 1 & 25 & & 0.674 \\
\hline Myalgia & 2 & 9 & & 1 & 25 & & 0.408 \\
\hline Erythema & 1 & 5 & & 1 & 25 & & 0.279 \\
\hline Chest pain & - & - & & 1 & 25 & & - \\
\hline Amyloidosis & - & - & & - & - & & - \\
\hline Family history & 20 & 83 & & 1 & $33^{* *}$ & & 0.115 \\
\hline Definitive/probable FMF & $8 / 0$ & & & $1 / 2$ & & & 0.055 \\
\hline Definitive/suspicious FMF & $8 / 16$ & & & $1 / 1$ & & & 0.582 \\
\hline
\end{tabular}

R202Q alleles were 53\% and 13\%, respectively, which is in concordance with previous results.

In the present study, we detected patients with the R202Q alteration together with the M694V mutation and non-M694V mutations (E148Q, V726A). Also, we detected that two patients were homozygous for R202Q. The R202Q alteration together with the M694V mutation was previously reported as a prevalent polymorphism for linkage disequilibrium. ${ }^{8}$ However, the R202Q substitution was shown in $20 \%$ of healthy controls, in $15 \%$ of patients with unknown mutations, and in $16 \%$ of patients with non-exon 10 mutations. ${ }^{11}$ Ozturk et al. ${ }^{10}$ similarly expressed that there were patients with the R202Q mutation that was not in linkage disequilibrium with M694V. Moreover, this study and another study from Greece showed that R202Q homozygous FMF patients did not carry any other disease-causing mutation. . $^{10,17}$ So far, the heterozygous R202Q alteration of MEFV genes has been shown to be associated with the E148Q, M680I and P396S mutations. ${ }^{10,18}$

Debate still continues over the phenotypeR202Q alteration relationship in FMF. Some studies reported that $\mathrm{R} 202 \mathrm{Q}$ is not associated with FMF and does not confer a significant risk of suffering the disease. ${ }^{11,12}$ Ozturk et al. ${ }^{10}$ suggested that $\mathrm{R} 202 \mathrm{Q}$ does not contribute to FMF when it is in the heterozygous state. However, when combined with another disease-causing mutation, the clinical spectrum appears. Thus, these authors stated that R202Q might be a disease-causing mutation in at least some FMF patients. Yigit et al. ${ }^{16}$ reported that there was a high association between the R202Q alteration and FMF, and that the R202Q alteration can be a cause of illness in homozygous form and should be included in routine molecular diagnosis of FMF patients. Similarly, we also thought that the R202Q alteration might lead to the disease in at least some FMF patients (if there is no another mutation).

Previous studies have examined whether the R202Q alteration of MEFV genes may cause FMF, but these studies did not assess the clinical effect of the R202Q alteration. Therefore, in this study, we also investigated the clinical significance of the R202Q alteration in patients with FMF. A comparison of the compound heterozygous mutations M694V/R202Q and M694V/other showed that the frequencies of symptoms and definitive FMF were lower in the M694V/R202 subgroup. However, there was no difference between isolated heterozygous R202Q alteration and other isolated heterozygous mutation. The findings showed that R202Q/M694V compound heterozygosity may be associated with a mild phenotype than compound heterozygous mutation of M694V.

In conclusion, R202Q has one more haplotype, which is not in linkage with M694V mutation. R202Q alteration of MEFV genes may be 
associated with FMF or FMF symptoms. However, clinical effect of R202Q alteration may not be as significant compared to compound heterozygous mutation of $\mathrm{M} 694 \mathrm{~V}$ in state combined with the M694V mutation.

\section{Declaration of conflicting interests}

The authors declared no conflicts of interest with respect to the authorship and/or publication of this article.

\section{Funding}

The authors received no financial support for the research and/or authorship of this article.

\section{REFERENCES}

1. Ozturk C, Halicioglu O, Coker I, Gulez N, Sutçuoglu $\mathrm{S}$, Karaca N, et al. Association of clinical and genetical features in FMF with focus on MEFV strip assay sensitivity in 452 children from western Anatolia, Turkey. Clin Rheumatol 2012;31:493-501.

2. Saatçi U, Ozen S, Ozdemir S, Bakkaloglu A, Besbas $\mathrm{N}$, Topaloglu R, et al. Familial Mediterranean fever in children: report of a large series and discussion of the risk and prognostic factors of amyloidosis. Eur $\mathrm{J}$ Pediatr 1997;156:619-23.

3. Padeh S, Berkun Y. Auto-inflammatory fever syndromes. Rheum Dis Clin North Am 2007;33:585623.

4. Sohar E, Gafni J, Pras M, Heller H. Familial Mediterranean fever. A survey of 470 cases and review of the literature. Am J Med 1967;43:227-53.

5. Ancient missense mutations in a new member of the RoRet gene family are likely to cause familial Mediterranean fever. The International FMF Consortium. Cell 1997;90:797-807.

6. Pras E, Aksentijevich I, Gruberg L, Balow JE Jr, Prosen L, Dean M, et al. Mapping of a gene causing familial Mediterranean fever to the short arm of chromosome 16. N Engl J Med 1992;326:1509-13.

7. Yilmaz R, Ozer S, Ozyurt H, Erkorkmaz U, Sahin $\mathrm{S}$. Familial Mediterranean fever gene mutations in the inner northern region of Turkey and genotype- phenotype correlation in children. J Paediatr Child Health 2009;45:641-5.

8. INFEVERS. The registry of familial Mediterranean fever (FMF) and hereditary autoinflammatory disorders mutations. Available from: http://fmf.igh.cnrs.fr/ ISSAID/infevers.

9. French FMF Consortium. A candidate gene for familial Mediterranean fever. Nat Genet 1997;17:25-31.

10. Oztürk A, Ozçakar B, Ekim M, Akar N. Is MEFV gene Arg202Gln (605 G>A) A Disease-Causing Mutation? Turk. J. Med. Sci 2008;38:205-8.

11. Bernot A, da Silva C, Petit JL, Cruaud C, Caloustian $\mathrm{C}$, Castet $\mathrm{V}$, et al. Non-founder mutations in the MEFV gene establish this gene as the cause of familial Mediterranean fever (FMF). Hum Mol Genet 1998;7:1317-25.

12. Aldea A, Calafell F, Aróstegui JI, Lao O, Rius J, Plaza $\mathrm{S}$, et al. The west side story: MEFV haplotype in Spanish FMF patients and controls, and evidence of high LD and a recombination "hot-spot" at the MEFV locus. Hum Mutat 2004;23:399.

13. Livneh A, Langevitz P, Zemer D, Zaks N, Kees S, Lidar T, et al. Criteria for the diagnosis of familial Mediterranean fever. Arthritis Rheum 1997;40:1879-85.

14. Tchernitchko D, Legendre M, Delahaye A, Cazeneuve C, Niel F, Goossens M, Amselem S, et al. Clinical evaluation of a reverse hybridization assay for the molecular detection of twelve MEFV gene mutations. Clin Chem 2003;49:1942-5.

15. Coker I, Colak A, Yolcu I, Türkön H, Nalbantoglu $\mathrm{SM}$. MEFV gene mutation spectrum in familial Mediterranean fever (FMF): a single center study in the Aegean region of Turkey. Z Rheumatol 2011;70:511-6.

16. Yigit S, Karakus N, Tasliyurt T, Kaya SU, Bozkurt N, Kisacik B. Significance of MEFV gene R202Q polymorphism in Turkish familial Mediterranean fever patients. Gene 2012;506:43-5.

17. Giaglis S, Papadopoulos V, Kambas K, Doumas M, Tsironidou V, Rafail S, et al. MEFV alterations and population genetics analysis in a large cohort of Greek patients with familial Mediterranean fever. Clin Genet 2007;71:458-67.

18. Karakus N, Yigit S, Inanir A, Inanir S, Toprak H, Okan S. Association between sequence variations of the Mediterranean fever gene and fibromyalgia syndrome in a cohort of Turkish patients. Clin Chim Acta 2012;414:36-40. 